ORIGINAL ARTICLE

\title{
Determine the Frequency of Endometrial Hyperplasia in Female with Abnormal Vaginal Bleeding
}

\author{
AYESHA NAEEM ${ }^{1}$, AMNA ASLAM ${ }^{2}$, AMBER-U-NISSA $^{3}$, TAYYABA RASHEED ${ }^{4}$, TANWEER AKHTAR ${ }^{5}$, ZAFREEN NAZ \\ GUDARO 6 \\ ${ }^{1}$ Associate Professor, Department of Obstetrics \& Gynaecology, Khawaja Muhammad Safdar Medical College/Allama lqbal Memorial \\ Teaching Hospital, Sialkot \\ ${ }^{2}$ Assistant Professor, Department of Obstetrics \& Gynaecology, Avicenna Medical College \& Hospital, Lahore \\ ${ }^{3}$ Lecturer, Chandka Medical College Larkana \\ ${ }^{4}$ Final Year MBBS, Ghulam Muhammad Mahar Medical College, Sukkur \\ ${ }^{5}$ Associate Professor, Department of Obstetrics \& Gynaecology, Shaikh Zayed Women Hospital, Shaheed Mohtarma Benazir Bhutto \\ Medical University, Larkana \\ ${ }^{6}$ Ultrasound Specialist, Department of Radiology, Dr. Sulaiman Al-Habib Hospital Riyadh, KSA \\ Correspondence to: Ayesha Naeem, Email: naeem1683@gmail.com, Cell: 03348112636
}

\begin{abstract}
Objective: To determine the frequency of endometrial hyperplasia in female with abnormal vaginal bleeding. Study Design: Cross-sectional

Place and Duration of Study: Department of Obstetrics \& Gynaecology, Allama lqbal Memorial Teaching Hospital, Sialkot from $1^{\text {st }}$ January 2021 to $31^{\text {st }}$ March 2021.

Methodology: One hundred and ten females with abnormal bleeding were presented in this study. Patients were aged between 40-65 years. Demographically details of age, weight, body mass index and socio economic status were recorded after taking written consent. Complete patients were undergone for transvaginal ultrasound. Frequency of endometrial hyperplasia was recorded.

Results: Mean age of the females was $47.16 \pm 7.53$ years with mean BMI $26.17 \pm 8.44 \mathrm{~kg} / \mathrm{m}^{2}$. Mean weight of the patients were $59.16 \pm 17.66 \mathrm{~kg}$. Most of the patients $65(59.09 \%)$ were from urban area and majority of the patients $70(63.64 \%)$ were illiterate. Sixty $(54.5 \%)$ cases were from low socio-economic status and $50(45.5 \%)$ had high socio-economic status. Endometrial hyperplasia was found in $25(22.73 \%)$ patients, in which $18(72 \%)$ had cystic hyperplasia, adenomatous hyperplasia found in $4(16 \%)$ and $3(12 \%)$ had atypical hyperplasia. Among 25 cases of hyperplasia, menorrhagia found in $15(60 \%)$, polymenorrhea found in $8(32 \%)$ and polymenorrhagia in $2(8 \%)$. Medical treatment were given to $20(80 \%)$ cases and surgical treatment were given to $5(20 \%)$.

Conclusion: The prevalence of endometrial hyperplasia was $22.73 \%$ among women with abnormal bleeding. It can be cure by early diagnosis and treatment.
\end{abstract}

Keywords: Transvaginal ultrasound (TVS), Endometrial hyperplasia, Abnormal vaginal bleeding, Menorrhagia

\section{INTRODUCTION}

Menstrual issues are highly morbid and afflict 1 in 5 women throughout their lives. Abnormal uterine bleeding (AUB) is specifically one of the most prevalent menstruation distressing issues. The menstrual disturbance epidemiology has shown that AUB prevalence is approximately 5-15 percent in poor countries, including Pakistan. ${ }^{1}$ Out of 1600 gynaecological cases, 400 AUB cases reported an AUB prevalence of $25 \%$ per 100 gypsy cases throughout the time period under study. Two hundred and forty one $(60 \%)$ individuals out of 400 AUB cases were recruited. Abnormal uterine bleeding risk factors include pathological conditions of women's genitals, disorders associated to pregnancy and systemic diseases. ${ }^{2}$

Hormone imbalance patterns (proliferative endometrial disorder, non-secretory endometriumwith stromal and glandular breakdown, pill effect and luteal phase defect), atrophic endometrium, endometrial polyp, terminal and endometrial hyperplasia and endometrial carcinoma are commonly detectable histologically in AUB. However, only around half of cases of AUB showed endometrial abnormalities and the clinical picture dominated the hormone imbalance pattern. ${ }^{3,4}$

In developing nations, the AUB is one of the most frequent cause of hysterectomy, yet $40 \%$ of cases were not linked to conclusive organic pathology. ${ }^{5}$ The associated problems, such as bleeding, bladder or bowel injury, infection, thrombosis, ovarian failure, and early starting menopause are typically associated with hysterectomy. ${ }^{6}$ In poor nations including Pakistan, the prevalence of abnormal uterine bleeding is approximately $5-15 \%$. One half of all women $45.5 y e a r s$ of age, $34 \% 47.8 \mathrm{yrs}$ of age and $90 \% 50.8$ years of age encounter menstrual trouble. ${ }^{1}$ Estimates indicate that approximately 6 percent of women between 25 and 44 years of age contact their general physician each year for excessive menstrual loss, about 35 percent of them in the hospital and 60 percent of them in the next 5 years for hysterectomy. There are more than 75000 hysterectomies per year presently, $25-30 \%$ of which are carried out with menstrual disorders. ${ }^{7}$

Hysterectomy is linked with a high rate of morbidity (ureteral injuries occur in $1 \%$ to $3 \%$ of the patients, atelectasis, fallopian tube prolapse, thromboembolic, myocardial infarction, stroke and renal failure) and is used as last prerogative by $\mathrm{m}$, due to size and location of the ureter. ${ }^{3}$ Minimal invasive surgery has faster healing, smaller incisions and short hospital stay. The treatment of atypical proliferative lesions from the endometrium as an alternative to hysterectomy was proven to be useful by hysteroscopic resection. - $10^{-10}$ As endometrium is the most accessible tissue for histopathological uterine bleeding 
assessment, many procedures for endometrial collection are performed, including dilation or curettage. ${ }^{11}$

\section{MATERIALS AND METHODS}

This cross-sectional study was conducted at Department of Obstetrics \& Gynaecology, Allama lqbal Memorial Teaching Hospital Sialkot from $1^{\text {st }}$ January 2021 to $31^{\text {st }}$ March 2021 and comprised of 110 patients with abnormal bleeding age between 40-65 years. Demographically details of age, weight, body mass index and socio economic status were recorded after taking written consent. All women who had uterine fibroid, comorbidities like hypertension, diabetes mellitus and those did not give any written consent were excluded. Complete patients were undergone for transvaginal ultrasound (TVS). Frequency of endometrial hyperplasia was recorded. Hyperplasia of the endometrium was identified as positive for endometrial thickness greater than $5 \mathrm{~mm}$. The data was entered and analyzed through SPSS-22.

\section{RESULTS}

Mean age of the females was $47.16 \pm 7.53$ years with mean body mass index $26.17 \pm 8.44 \mathrm{~kg} / \mathrm{m}^{2}$. Mean weight of the patients were $59.16 \pm 17.66 \mathrm{~kg}$. Most of the patients 65 $(59.9 \%)$ were from urban area and majority of the patients $70(63.6 \%)$ were illiterate. $60(54.5 \%)$ cases were from low socioeconomic status and $50(45.5 \%)$ had high socioeconomic status (Table 1 ).

Endometrial hyperplasia was found in 25 (22.73\%) patients, in which $18(72 \%)$ had cystic hyperplasia, adenomatous hyperplasia found in 4 (16\%) and 3 (12\%) had atypical hyperplasia (Table 2). Among 25 cases of hyperplasia, menorrhagia found in 15 (60\%), polymenorrhoea found in $8(32 \%)$ and polymenorrhagia in $2(8 \%)$ [Table 3]. Medical treatment was given to $20(80 \%)$ cases and surgical treatment were given to 5 (20\%) [Table 4].

Table 1: Baseline details demographics of enrolled cases $(n=110)$

\begin{tabular}{|l|c|c|}
\hline Variable & No. & $\%$ \\
\hline Mean age (years) & \multicolumn{2}{|c|}{$47.16 \pm 7.53$} \\
\hline Mean BMI $\left(\mathrm{kg} / \mathrm{m}^{2}\right)$ & \multicolumn{2}{|c|}{$59.17 \pm 8.44$} \\
\hline Mean weight $(\mathrm{kg})$ & 65 & 59.9 \\
\hline Area & 45 & 40.1 \\
\hline Urban & 40 & 36.4 \\
\hline Rural & 70 & 63.6 \\
\hline Literacy & \\
\hline Yes & 60 & 54.5 \\
\hline No & 30 & 45.5 \\
\hline Socioeconomic status &
\end{tabular}

Table 2: Frequency of endometrial hyperplasia and their types $(\mathrm{n}=110)$

\begin{tabular}{|l|c|c|}
\hline Vriable & No. & $\%$ \\
\hline Endometrial hyperplasia & 25 & 22.73 \\
\hline Yes & 85 & 77.27 \\
\hline No & 18 & 72.0 \\
\hline Types (n=25) & 4 & 16.0 \\
\hline Cystic hyperplasia & 3 & 12.0 \\
\hline Adenomotous hyperplasia & \multicolumn{2}{|l|}{} \\
\hline Typical hyperplasia &
\end{tabular}

Table 3: Pattern of bleeding among endometrial hyperplasia cases $(\mathrm{n}=25)$

\begin{tabular}{|l|c|c|}
\hline Pattern of bleeding & No. & $\%$ \\
\hline Menorrhagia & 15 & 60.0 \\
\hline Polymenorrhea & 8 & 32.0 \\
\hline Polymenorrhagia & 2 & 8.0 \\
\hline
\end{tabular}

Table 4: Association of treatment among cases $(n=25)$

\begin{tabular}{|l|c|c|}
\hline Treatment & No. & $\%$ \\
\hline Medical & 20 & 80.0 \\
\hline Surgical & 5 & 20.0 \\
\hline
\end{tabular}

\section{DISCUSSION}

The prominent health problem in women with multifactorial etiology is abnormal vaginal bleeding. Transvaginal ultrasound can be utilized to diagnose structural reasons of irregular bleeding as a first-line imaging mode. ${ }^{12}$ The greatest indicators of eventual endometrial cancer include aging and the spread of the intraepithelial endometrial neoplasia. ${ }^{13}$

In the present study, mean age was $47.16 \pm 7.53$ years with mean BMl $26.17 \pm 8.44 \mathrm{~kg} / \mathrm{m}^{2}$. The findings were comparable to the previous study. ${ }^{14}$ This study showed that most of the patients $65(59.09 \%)$ were from urban area and majority of the patients $70(63.64 \%)$ were illiterate. 60 $(54.5 \%)$ cases were from low socio-economic status and $50(45.5 \%)$ had high socio-economic status. These showed resemblance to the previous report. ${ }^{14}$ Babacan et $\mathrm{al}^{15}$ reported that mean age was $49.5 \pm 12.9$ years in their patients. In patients of this age the fact that the number of ovarian follicles decreases the menopause occurs, and their gonadotrophic stimulus resistance increases, leading to a low concentration of estrogen level which is insufficient to maintain the typical endometrium development.

This study showed that $22.73 \%$ of the females had endometrial hyperplasia. On the other hand, $24.7 \%$ endometrial hyperplasia has been described by Muzaffar and others ${ }^{16}$ and $30.3 \%$ by Wahda et al. ${ }^{17}$

Abid et $\mathrm{al}^{18}$ reported that $1 \%$ among 119 reproductive age groups, of the 77 perimenopausal women with $6.5 \%$ endometrial hyperplasia, of the after menopausal women of $13.2 \%$. Munawar et $\mathrm{al}^{19}$ assessed the causes of bleeding in postmenopausal women and the most common diagnosis was endometrial hyperplasia (48\%). Dilation and curettage (D\&C) in excessive and atypical uterine bleeding was conducted by $\mathrm{Adil}^{20}$ for two years in a 2-year trial. $8.8 \%$ for adenomatous hyperplasia, incidence of cystic endometrial hyperplasia was $32.8 \%$. It was the most common in our study among endometrial hyperplasia (72\%).

In most cystic hyperplasia patients, the bleeding rate is heavy but regular, whereas in complicated, atypical hyperplasia the pattern is irregular and shows the severity of the condition. In our study, $60 \%$ of cystic hyperplasia patients only experienced menorrhagia. There was no special value for endometrial hyperplasia diagnoses because four individuals out of 25 had an endometrial thickness of 5 to $6 \mathrm{~mm}$. A research by Bakos and Heimer ${ }^{21}$ have found that transvaginal ultrasonography in women with irregular bleeding is as successful as D\&C. $76 \%$ of endometrial abnormalities may be detected by Doppler endovaginal ultrasound. ${ }^{22}$

In current study, medical treatment was given to 20 $(80 \%)$ cases and surgical treatment was given to 5 
(20\%).Management options include stopping exogenous substances and removing oestrogen generating ovarian tumors. The severity of the disease, the age and wishes of patients for future children depend on medical and surgical treatment. For endometrial hyperplasia, short-term usage of Gonadotrophin releasing hormone analog is used. Colacurci et $\mathrm{al}^{23}$ employed gonadotrophin-releasing shortterm (3 months) therapy analogous to women in premenopausal conditions. The symptoms were extended, free and there was a low rate of side effects. The identification of endometrial hyperplasia and early treatment remain essential since they represent the antecedents of endometrial cancer.

\section{CONCLUSION}

The prevalence of endometrial hyperplasia was $22.73 \%$ among women with abnormal bleeding. It can be cure by early diagnosis and treatment.

\section{REFERENCES}

1. Harlow SD, Campbell OMR. Epidemiology of menstrual disorders in developing countries: a systematic review. BJOG 2004;111:6-16.

2. Munro MG, Critchley HO, Broder MS, Fraser IS. FIGO Working Group on Menstrual Disorder. FIGO classification system (PALM-COEIN) for causes of abnormal uterine bleeding in non gravid women of reproductive age. Int $\mathrm{J}$ Gynaecol Obstet 2011;113:3-13.

3. Anastasiadis PG, Skaphida PG, Koutlaki NG, Galazios GC, Tsikouras PN, Liberis VA. Descriptive epidemiology of endometrial hyperplasia in patients with abnormal uterine bleeding. Eur J Gynaecol Oncol 2000;21:131-4.

4. Longacre $\mathrm{T}$, Atkins $\mathrm{K}$, Kempson R, Hendrickson M. The uterine corpus. In: Sternberg's Diagnostic Surgical Pathology. Philadelphia: Lippincott William \& Wilkins, 2005: 2184-2277.

5. Heavy Menstrual Bleeding. NICE Clinical Guidelines, No.44. National Collaborating Centre for Women's and Children's Health. London: RCOG Press; 2007; 24-7.

6. Glasser $\mathrm{MH}$. Commentary on 'Ten-year follow-up of a randomised controlled trial comparing bipolar endometrial ablation with balloon ablation for menorrhagia' BJOG 2013;120:970.

7. Bradley LD. Abnormal uterine bleeding. Nurse Pract 2005;30:38-51.

8. Herman MC, van den Brink MJ, Geomini PM, van Meurs HS, Huirne JA, Eising HP, et al. Levonorgestrel releasing intrauterine system (Mirena) versus endometrial ablation (Novasure) in women with heavy menstrual bleeding: a multicentre randomised controlled trial. BMC Womens Health 2013;13:32.

9. Ajao MO, El-Nashar SA, Khan Z, Hopkins MR, Creedon DJ, Famuyide AO. Nonresectoscopic endometrial ablation in high-risk surgical patients: a cohort study. J Minim Invasive Gynecol 2013;20:487-91.

10. Litta P, Bartolucci C, Saccardi C, Codroma A, Fabris A Borgato S, Conte L. Atypical endometrial lesions: hysteroscopic resection as an alternative to hysterectomy. Eur J Gynaecol Oncol 2013;34:51-3.

11. Mazur MT, Kurman RJ. Methods of endometrial evaluation. In: Mazur MT, Kurman RJ. Diagnosis of Endometrial Biopsies and Curettings. Berlin: Springer, 2005; 1-6.

12. Wheeler KC, Goldstein SR. Transvaginal ultrasound for the diagnosis of abnormal uterine bleeding. Clin Obstet Gynecol 2017;1;60(1):11-7

13. Vetter MH, Smith B, Benedict J, Hade EM, Bixel $K$ Copeland LJ, et al. Preoperative predictors of endometrial cancer at time of hysterectomy for endometrial intraepithelial neoplasia or complex atypical hyperplasia. Am J Obstet Gynecol 2020; 222(1):60-e1.

14. Takreem A, Danish N, Razaq S. Incidence of endometrial hyperplasia in 100 cases presenting with polymenorrhagia/menorrhagia in perimenupausal women. $\mathrm{J}$ Ayub Med Coll Abbottabad 2009;21(2).

15. Babacan A, Gun I, Kizilaslan C, Ozden O, Muhcu M, Mungen E, Atay V. Comparison of transvaginal ultrasonography and hysteroscopy in the diagnosis of uterine pathologies. International journal of clinical and experimental medicine. 2014;7(3):764

16. Muzaffar M, Akhtar KA, Yasmin S, Rehman M, lqbal W, Khan MA. Menstrual irregularities with excessive blood loss: a clinico-pathological correlation. JPMA 2005;55(11):486.

17. Wahda MT, Manal TA, Safwan I. Histopathological interpretation of abnormal uterine bleeding after the age of 40 year. Iraqi Postgrad Med J 2010;9:274-82.

18. Abid M, Hashmi AA, Malik B, Haroon S, Faridi N, Edhi MM et al. Clinical pattern and spectrum of endometrial pathologies in patients with abnormal uterine bleeding in Pakistan: need to adopt a more conservative approach to treatment. BMC Womens Health 2014;14:132.

19. Munawar S, Kamal F, Munawar F. Morphological pattern of endometrial lesions in postmenopausal bleeding. Biomedica 2018;34(1):11.

20. Adil $F$. D\&C in excessive and abnormal uterine bleeding (2 year study). Obst Gynae B Unit Dow Medical College Karachi 1997.

21. Bakos O, Heimer G. Transvaginal Ultrasonography evaluation of the endometirum related to the histological findings in pre-and permenopausal women. Gynaecol Obstet Invest 1998;45(3):199204.

22. el-Ahmady O, Gad M, el-Sheimy R, Halim AB, Eissa S, Hassan F, et al. Comparative study between sonography pathology and UGP in women with periomenopausal bleeding. Anticancer Res 1996;16(4B):2309-13.

23. Colacurci N, De Placido G, Mollo A, Perino A, Cittadini E. Short term use of Goserlin depot in the treatment of dysfunctional uterine bleeding. Clin Exp Obstet Gynecol 1995;22(3):212-9. 